\title{
Model Pembelajaran Student Teams Achievement Divisions dengan Media Pop Up Card untuk Meningkatkan Hasil Belajar Biologi Kelas XI IPA 1 SMA Siliwangi Bogor
}

\author{
Fanny Nadia Hardjo ${ }^{1)}$, Rita Retnowati ${ }^{2)}$, Teti Rostikawati ${ }^{2)}$ \\ Universitas Pakuan Bogor Jawa Barat \\ e-mail: fannynadia99@yahoo.com
}

\begin{abstract}
Abstact: This study a Classroom Action Research (CAR), with subject 23 student of class XI Science-1. The aim of this study to increase the students learning outcome biology material, through the use of Student Teams Achievement Divisions (STAD) with Pop Up Card media as learning model of biology. The research process was conducted in two cycles. In every cycle there are 4 stages: Action Planning, Implementation Measures, Observations and Reflections. At the end of each cycle of tests carried out with instruments that have tested the validity and reliability. The result showed the implementation of STAD model with Pop Up Card media can increase the result of learning biology, shown by the average of students result in grade XI Science-1in cycle 1 is 70,1 , and in cycles 2 becoming 77,0 while the average of students activity in cycle 1 about 78,01\%, and in cycles 2 becoming 84,46\%. Based on the achieved result can be concluded then the application Student Teams Achievement Divisions with Pop Up Card media can increase activity and students learning result in biology at Grade XI Science-1 SMA Siliwangi Bogor.
\end{abstract}

Kata Kunci: Student Teams Achievement Divisions, Pop Up Card and learning outcome

Abstak: Penelitian ini merupakan Penelitian Tindakan Kelas (PTK), dengan subyek penelitian 23 siswa kelas XI IPA-1 di SMA Siliwangi Bogor. Penelitian ini bertujuan meningkatkan hasil belajar biologi melalui penggunaan model Student Teams Achievement Divisions (STAD) dengan edia Pop Up Card. Penelitian dilakukan dalam dua siklus. Setiap siklus ada 4 tahap yaitu perencanaan, pelaksanaan tindakan, observasi dan refleksi. Setiap akhir siklus dilakukan tes dengan instrumen yang valid dan reliabel. Hasil penelitian menunjukkan penggunaan model STAD dengan media Pop Up Card dapat meningkatkan hasil belajar biologi, terlihat dari rata-rata hasil belajar siswa pada siklus 1 sebesar 70,1 dan siklus 2 sebesar 77,0; sedangkan nilai rata-rata aktivitas siswa pada siklus 1 yaitu 78,01\% dan pada siklus 2 menjadi 84,46\%. Berdasarkan hasil yang dicapai maka dapat disimpulkan penggunaan model Student Teams Achievement Divisions dengan media Pop Up Card dapat meningkatkan aktivitas dan hasil belajar biologi siswa di kelas XI IPA-1 di SMA Siliwangi Bogor.

Keywords: Model pembelajaran Student Teams Achievement Division, Pop Up Card, dan Hasil belajar

\section{PENDAHULUAN}

Keberhasilan proses belajar mengajar merupakan hal utama yang diharapkan dalam melaksanakan pendidikan di sekolah. Komponen utama dalam kegiatan belajar mengajar adalah siswa dan guru. Dalam hal ini siswa yang menjadi subjek belajar, bukan menjadi objek belajar. Guru harus memiliki kemampuan untuk mengembangkan metode pembelajaran dan pemanfaatan media pembelajaran agar penyajian materi lebih menarik dan tujuan pembelajaran dapat dicapai dengan baik.

SMA Siliwangi Bogor merupakan salah satu sekolah yang terdapat di kota Bogor dan memiliki jumlah kelas serta peserta didik yang cukup sedikit. Di dalam proses belajar mengajarnya, SMA
Siliwangi Bogor menetapkan Kriteria Ketuntasan Minimal (KKM) untuk mata pelajaran biologi pada tahun pelajaran 2016/2017, yakni sebesar 75. Siswa dengan nilai di atas 75 dinyatakan lulus, sedangkan siswa dengan nilai di bawah 75 dinyatakan belum lulus sehingga perlu mengikuti remidial.

Berdasarkan observasi di SMA Siliwangi Bogor yang pada bulan Mei 2016, khususnya kelas XI IPA 1 dan wawancara dengan guru biologi serta sebagian siswa XI IPA 1 dapat diketahui bahwa sebagian besar siswa mengalami kesulitan dan merasa kurang antusias dalam pembelajaran biologi. Hal ini disebabkan proses pembelajaran berlangsung secara monoton, sehingga minat dan motivasi belajar siswa di kelas kurang. Data yang diperoleh 
menunjukkan bahwa nilai rata-rata tahun pelajaran 2015/2016 belum mencapai batas ketuntasan minimal yaitu 75. Hal ini kemungkinan disebabkan oleh penggunaan metode yang kurang tepat, siswa yang kurang aktif dan kreatif dalam mengikuti pelajaran.

Informasi yang didapat berdasarkan wawancara dengan beberapa siswa di kelas XI IPA 1, mengungkapkan bahwa proses belajar mengajar biologi yang dijumpai di kelas masih menggunakan metode konvensional, yaitu ceramah dan menulis yang menjadikan guru sebagai pusat kegiatan belajar mengajar. Siswa pada umumnya hanya mendengarkan, membaca dan menghafal informasi yang diperoleh tanpa berupaya untuk menemukan sendiri konsep-konsep yang dipelari tersebut sehingga konsep yang tertanam tidak kuat dan siswa tidak memiliki motivasi dalam mengikuti pembelajaran biologi. Hasil yang dicapai dari metode tersebut kurang maksimal dan keaktifan siswa serta potensi yang ada pada siswa kurang terlihat.

Berdasarkan berbagai permasalahan yang dihadapi di atas, maka perlu adanya perbaikan kualitas proses pembelajaran untuk meningkatkan motivasi siswa maupun hasil belajar siswa dalam pembelajaran biologi baik itu tindakan berupa penggunaan strategi pembelajaran maupun pemanfaatan media yang dapat diterapkan untuk mencapai tujuan pembelajaran yang diinginkan yang disesuaikan dengan kondisi sekolah. Penerapan strategi pembelajaran maupun media pembelajaran yang baru atau bervariasi diharapkan kegiatan pembelajaran dapat berlangsung efektif, efisien dan menarik yang nantinya dapat membentuk proses pembelajaran yang berkualitas yang pada akhirnya diharapkan dapat meningkatkan mutu hasil pembelajaran.

Salah satu alternatif pemecahan untuk mengatasi masalah tersebut adalah dengan menerapkan model pembelajaran kooperatif Student Teams Achievment Divisions (STAD) dengan media Pop Up Card. Menurut Suprijono (2009), model pembelajaran kooperatif meliputi semua jenis kerja kelompok yang dipimpin atau diarahkan oleh guru. Secara umum pembelajaran kooperatif dianggap lebih diarahkan oleh guru, dimana guru menetapkan tugas dan pertanyaan-pertanyaan serta menyediakan bahan-bahan dan informasi yang dirancang untuk membantu peserta didik menyelesaikan masalah. Huda (2014) menyatakan STAD merupakan salah satu strategi pembelajaran kooperatif yang di dalamnya beberapa kelompok kecil siswa dengan level kemampuan akademik berbeda-beda yang saling bekerja sama untuk menyelesaikan tujuan pembelajaran.

Langkah-langkah pembelajaran STAD menurut Rusman (2012) adalah: (1) Penyampaian tujuan pembelajaran dan motivasi, (2) Pembagian kelompok, siswa dibagi ke dalam beberapa kelompok yang terdiri dari 4-5 siswa yang memprioritaskan heterogenitas (keragaman) kelas dalam prestasi akademik, gender/jenis kelamin, ras atau etnik, (3) Presentasi dari guru, guru menyampaikan materi pelajaran dengan terlebih dahulu menjelaskan tujuan pokok yang akan dipelajari. Guru memberi motivasi siswa agar dapat belajar dengan aktif dan kreatif di dalam proses pembelajaran guru dibantu media, (4) Kerja tim, siswa belajar dalam kelompok yang telah dibentuk. Guru menyiapkan lembaran kerja sebagai pedoman bagi kerja kelompok, sehingga semua anggota menguasai dan masing-masing memberikan bimbingan, dorongan dan bantuan. Kerja tim merupakan ciri penting dari STAD, (5) Kuis (evaluasi), guru mengevaluasi hasil belajar melalui pemberian kuis tentang materi yang dipelajari dan juga melakukan penilaian terhadap persentasi hasil kerja masing-masing kelompok, dan (6) Penghargaan tim, Setelah pelaksanaan kuis, guru memeriksa hasil kerja siswa dan diberikan angka rentang 0-100. Untuk menghitung skor kelompok dibuat rata-rata dari skor individu dan diakumulasikan. Penghargaan (Reward) yang akan diterima mencakup tim baik (good team), tim baik sekali (Great team) dan tim istimewa (Super team).

Ada tiga keuntungan menggunakan model pembelajaran STAD, yaitu semua siswa memiliki kesempatan yang sama menerima reward setelah menyelesaiakan suatu materi pelajaran, semua siswa mempunyai kemungkinan yang sama untuk mencapai hasil belajar yang tinggi, dan reward yang diberikan memberikan motivasi berprestasi kepada kelompok yang dapat digunakan untuk memberikan motivsi berprestasi semua siswa. Penelitian yang relevan juga dilakukan oleh Haerullah (2013) yang menerapkan model pembelajaran STAD di kelas VII MTs Negeri Kota Ternate menunjukkan terdapat peningkatan aktivitas dan hasil belajar pada konsep pencemaran lingkungan. Penelitian tentang penggunaan model pembelajaran kooperatif tipe STAD dengan metode eksperimen di kelas VIII SMP 2 Labuan Deli pada pelajaran Fisika juga mampu meningkatkan aktivitas dan hasil belajar siswa melalui pembelajaran dengan dua siklus (Kesuma, 2013).

Berdasarkan permasalahan dan hasil penelitian yang relevan, maka penelitian ini bertujuan meningkatkan aktivitas dan hasil belajar siswa kelas XI di SMA Siliwangi Bogor pada materi Struktur dan Fungsi Sel menggunakan model pembelajaran kooperatif STAD 
dengan media Pop-up Card. Hasil penelitian ini diharapkan dapat bermanfaat untuk guru dalam menghasilkan pengetahuan yang relevan untuk memperbaiki proses pembelajaran dan menambah ilmu pengetahuan tentang penerapan model STAD dan penggunaan media Pop-up Card terhadap kualitas proses dan hasil belajar biologi.

\section{METODE PENELITIAN}

\section{Hasil Penelitian}

Penelitian ini merupakan penelitian tindakan kelas yang dilaksanakan di kelas XI IPA 1 SMA Siliwangi Bogor pada awal semester satu tahun ajaran 2016/2017. Tahapan dalam penelitian tindakan kelas diawali dengan identifikasi pertanyaan penelitian, mengumpulkan informasi secara bersamasama, menganalisis dan mengintepretasikan informasi, dan mengembangkan rencana tindakan (Fraenkel dan Wallen, 2006). Perencanaan (planning) yang dibuat selanjutnya diimplementasikan (acting) sekaligus dilakukan pengamatan (observing), dan refleksi (reflecting). Kegiatan ini disebut dengan satu siklus. Siklus akan berakhir jika hasil penelitian yang diperoleh telah memenuhi indikator keberhasilan yang ditetapkan.

Proses pembelajaran yang telah dilaksanakan pada kelas XI SMA Siliwangi Bogor, sesuai jadwal penelitian dan jadwal pelajaran biologi kelas XI IPA 1 dengan setiap pertemuan berlangsung selama $2 \mathrm{x}$ 40 menit dan pada satu siklus terdapat 3 kali pertemuan. Penelitian dilaksanakan dalam dua siklus dengan jumlah keseluruhan ada 6 kali pertemuan. Deskripsi tindakan sesuai dengan langkah dalam model pembelajaran STAD.

Teknik pengumpulan data pada penelitian ini terdiri dari beberapa instrumen, yaitu: (1) Observasi dengan mengamati proses pelaksanaan tindakan, pengaruh, kendala dan masalah yang timbul selama proses tindakan berlangsung dan dilakukan terhadap fokus permasalahan yang ada; (2) tes hasil belajar yang dilakukan untuk mengukur kemampuan siswa, baik kemampuan awal, perkembangan atau peningkatan selama diberikan tindakan; (3) angket motivasi siswa yang berisi tentang respon siswa terhadap serangkaian pembelajaran yang telah mereka lalui; (4) catatan lapangan yang berisikan tentang apa yang dilihat, didengar, dialami dan dipikirkan peneliti selama berlangsungnya kegiatan berupa gambaran umum dikelas selama proses pembelajaran; dan (5) lembar diskusi siswa (LDS) untuk melihat hasil kerja secara berkelompok dan member kesempatan kepada siswa untuk menemukan konsep-konsep pembelajaran.

Pada tahap refleksi, seluruh data dari hasil penelitian di lapangan diolah dan dianalisis kemudian dievaluasi dan dilihat indikator keberhasilannya. Teknik analisis data dilakukan secara deskriptif kuantitatif. Hasil refleksi ini akan menjadi dasar dalam merencanakan tindakan yang akan diterapkan untuk siklus berikutnya.

Indikator keberhasilan penelitian tindakan kelas ini adalah aktivitas siswa telah mencapai $75 \%$, kriteria keberhasilan individu dalam mencapai kriteria ketuntasan minimum (KKM) yang telah ditetapkan pada mata pelajaran biologi yaitu 75 , dan tercapainya kompetensi secara klasikal jika $75 \%$ siswa mencapai KKM.

\section{HASIL DAN PEMBAHASAN}

Persentase aktivitas siswa pada saat proses pembelajaran baik on task (kegiatan yang dilakukan sesuai dengan kegiatan belajar mengajar) maupun off task (kegiatan yang dilakukan diluar kegiatan belajar mengajar) pada siklus 1 pertemuan 1 dan 2 ditunjukkan dalam Gambar 1, serta aktivitas siswa pada pertemuan 1 dan 2 ditunjukkan pada Gambar 2.

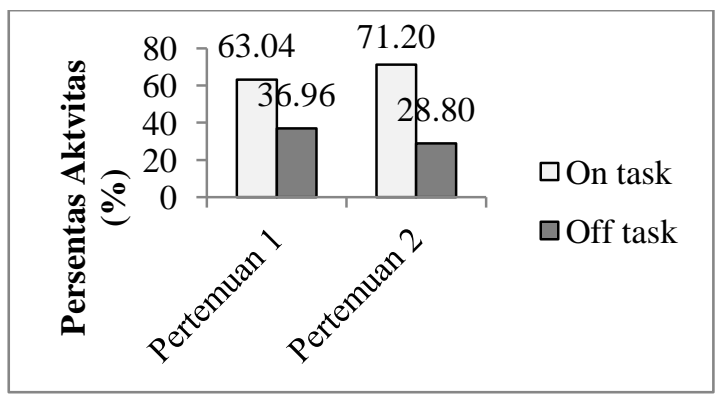

Gambar 1. Aktivitas siswa pada siklus 1

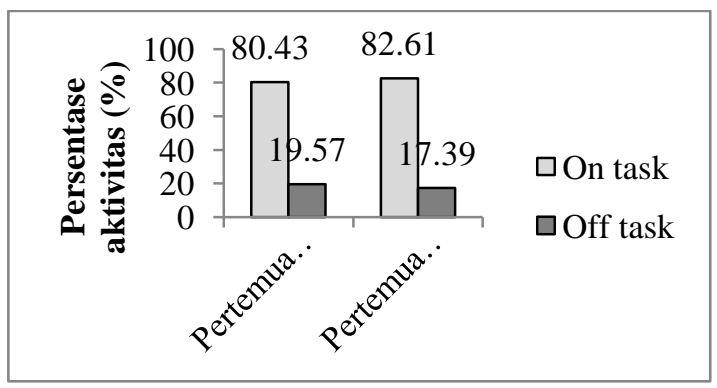

Gambar 2. Aktivitas siswa pada siklus 2

Gambar 1 dan 2 menunjukkan bahwa penggunaan pembelajaran kooperatif STAD menggunakan Pop Up Card menyebabkan peningkatan aktivitas siswa pada kegiatan on task dari pertemuan 1 dan pertemuan 2 baik pada siklus 1 maupun siklus 2, sedangkan aktivitas siswa pada kegiatan off task mengalami penurunan.

Perolehan hasil belajar siswa pada siklus 1 dan 2 ditunjukkan oleh Gambar 3, sedangkan perolehan 
KKM pada siklus 1 dan 2 terdapat pada Gambar 4.

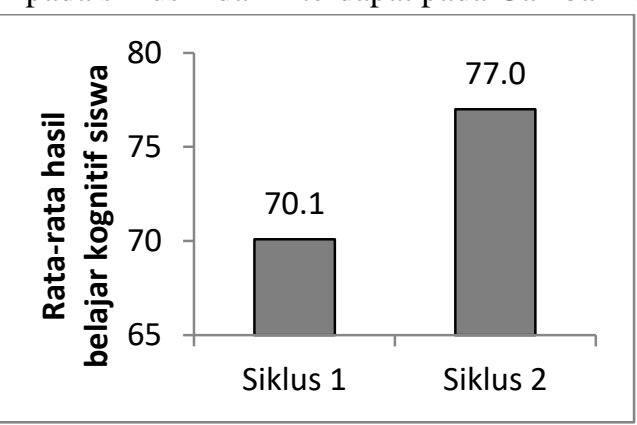

Gambar 3. Hasil belajar pada siklus 1 dan 2

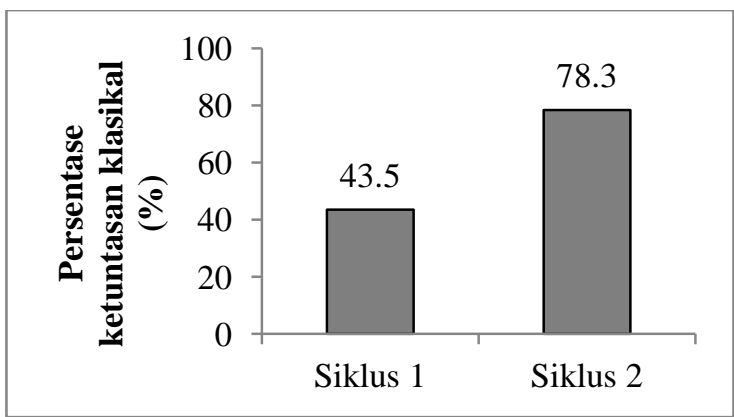

Gambar 4. Perolehan ketuntasan klasikal siklus 1 \& 2

Gambar 3 menunjukkan hasil belajar siswa mengalami peningkatan dari siklus 1 ke siklus 2 sebesar 6,9. Hal ini berdampak terjadinya peningkatan ketuntasan klasikal dari siklus 1 ke siklus 2 sebesar $34,78 \%$.

\section{Pembahasan}

Berdasarkan hasil penelitian yang diperoleh pada siklus 1 dan 2 menunjukkan pengguanaan model pembelajaran STAD dengan media Pop Up Card dapat meningkatkan hasil belajar siswa dalam pembelajaran biologi di kelas XI IPA 1 SMA Siliwangi Bogor. Hasil belajar yang dimaksud adalah perolehan hasil test kognitif. Rata-rata Hasil belajar pada siklus 1 masih kurang dari nilai KKM sebesar 70,1 dengan persentase ketuntasan klasikal sebesar $43,45 \%$. Belum maksimalnya hasil belajar siswa dikarenakan perolehan aktivitas siswa pada siklus satu masih kurang baik.

Aktivitas on task dan off task siswa pada siklus 1 pertemuan 1 sebesar 63,04\% untuk on task dan 36,96\% untuk off task. Sedangkan pada siklus 1 pertemuan 2 sebesar $71,20 \%$ untuk on task dan $28,80 \%$ untuk off task. Pada siklus ini guru memberikan LDS yang harus dikerjakan oleh setiap kelompok, akan tetapi hanya beberapa orang saja yang aktif mengerjakan dan siswa juga kurang kooperatif dalam mengerjakan soal-soal yang terdapat pada LDS. Masih banyak kegiatan siswa yang hanya mengobrol datau memperdulikan tugas yang diberikan oleh guru. Penilaian afektif siswa yang diukur dengan menggunakan angket yang diberikan kepada siswa pada tiap akhir siklus menunjukkan data bahwa pada siklus 1 ranah afektif siswa terhadap pembelajaran biologi adalah sebesar $65,21 \%$.

Aktivitas guru pada siklus 1 ini masih terbilang rendah. Setelah dilakukan tindakan pada siklus I ketuntasan belajar siswa baru mencapai $43,48 \%$. Hasil ini belum mencapai target yang direncanakan, yaitu $75 \%$ siswa tuntas. Berdasarkan hasil pengamatan pada tahap-tahap pelaksanaan model pembelajaran guru kurang mampu untuk memotivasi siswa sehingga siswa masih kurang antusias untuk mengikuti pelaksanaan pembelajaran. Guru juga masih kurang efektif menggunakan waktu dan belum menguasai langkah-langkah model pembelajaran dan kurang mengkomunikasikan tujuan pembelajaran pada siswa. Oleh karena itu, penelitian dilanjutkan pada siklus 2 .

Setelah refleksi terhadap siklus 1 , perencanaan untuk siklus 2 difokuskan pada perubahan strategi pembelajaran dan pengurangan jumlah anggota setiap kelompok sehingga banyaknya kelompok makin banyak. Hasil pengamatan terhadap proses pembelajaran di siklus 2 menunjukkan aktivitas siswa pada pertemuan 1 on task sebesar $80,43 \%$ dan off task sebesar $19,57 \%$, sedangkan aktivitas siswa pada pertemuan 2 sebesar $82,61 \%$ untuk on task dan $17,39 \%$ untuk off task. Aktivitas guru juga mengalami perkembangan dan lebih terlihat lancar pada siklus 2. Peningkatan aktivitas siswa dan guru pada siklus 2 berdampak pada peningkatan hasil belajar pada aspek kognitif. Perolehan hasil belajar siswa menunjukkan rata-rata 77 dengan ketuntasan klasikal sebesar $78,26 \%$. Hasil yang diperoleh pada siklus 2 telah melebihi indikator keberhasilan yang ditentukan yaitu $75 \%$.

Peningkatan aktivitas dan hasil belajar yang sudah mencapai KKM memang terlihat pada saat proses pembelajaran. Guru di kelas sudah bisa melaksanakan pembelajaran dengan baik dengan menggunakan model dan media pembelajaran. Pada siklus 2 ini siswa lebih aktif berdisikusi dan dapat dengan mudah mengikuti pembelajaran, karena guru telah mampu mengarahkan siswa di kelas. Guru juga telah melaksanakan tugasnya untuk memotivasi siswa sehingga siwa termotivasi untuk mengikuti pembelajaran

Peningkatan aktivitas dan hasil belajar siswa dipengaruhi oleh kegiatan pembelajaran yang dilaksanakan di kelas. Pembelajaran yang menyenangkan akan menimbulkan sifat positif terhadap pembelajaran, sehingga akan berpengaruh 
terhadap hasil belajar yang dicapai oleh siswa. Hal ini sejalan dengan pendapat Syah (2006) yang menyatakan bahwa sikap siswa yang positif dalam memandang guru dan mata pelajaran yang diajarkan merupakan pertanda awal yang baik bagi proses belajar siswa tersebut. Cara pandang siswa yang positif merupakan bentuk respon terhadap apa yang di rasakan selama pembelajaran berlangsung.

Besarnya peningkatan persentase aktivitas dan ketuntasan klasikal pada siklus 1 dan 2 disebabkan oleh penggunaan model pembelajaran kooperatif STAD. Model ini menuntut siswa untuk menyelesaikan LDS secara berkelompok. Setiap anggota kelompok berperan aktif dalam penyelesaian LDS. Menurut Huda (2014), STAD merupakan salah satu strategi pembelajaran kooperatif yang di dalamnya terdiri dari beberapa kelompok kecil siswa dengan level kemampuan akademik berbeda-beda untuk saling bekerja sama menyelesaikan tujuan pembelajaran melalui permasalahan yang diberi oleh guru. Penggunaan model pembelajaran STAD lebih menekankan pada prosesnya. Pembelajaran yang berpusat kepada siswa mendorong siswa untuk lebih aktif dalam menemukan jawaban sendiri atas permasalahan yang dihadapi baik melalui percobaan maupun pencarian informasi. Belajar secara berkelompok memberi kesempatan kepada siswa akan memperoleh pengetahuan sendiri melalui pengalaman secara langsung dan dapat mendorong sikap ilmiah pada diri siswa seperti sikap hasrat ingin tahu, ktitis, terbuka dan kerja sama. Pelaksanan proses pembelajaran memerlukan media untuk lebih memudahkan siswa dalam memahami materi yang dibahas. Salah satu jenis media pembelajaran adalah Pop Up Card.

Penggunaan media Pop Up Card sebagai alat bantu guru untuk menyajikan materi kepada siswa dengan bentuk media yang kreatif, sehingga proses pembelajaran siswa di dalam kelas tidak membosankan dan memotivasi siswa dalam belajar. Pada dasarnya media Pop Up Card merupakan cara visual dan prasarana grafis lainnya untuk membentuk kesan pada otak siswa pada saat proses pembelajaran. Dengan demikian, cara alami kerja otak dilibatkan sejak awal. Ini berarti, mengingat informasi akan lebih mudah dan lebih bisa diandalkan daripada mendengarkan atau membaca buku secara langsung materi yang akan diajarkan kepada siswa.

Kusuma (2013) dalam penelitiannya dengan menggnakan buku Pop-Up Cerita Rakyat Bledhug Kuwu mengungkapkan bahwa Pop-Up dapat membuat pembaca tertarik dalam mengikuti ceritanya karena mereka menanti kejutan apa lagi yang akan diberikan di halaman selanjutnya. Buku Pop-up mempunyai kemampuan untuk memperkuat pesan yang ingin disampaikan dalam sebuah cerita sehingga lebih jelas dan menarik. Tampilan visual dalam bentuk tiga dimensi yang membuat cerita semakin terasa nyata ditambah lagi dengan kejutan yang diberikan dalam setiap halamannya. Gambar dapat secara tiba-tiba muncul dari balik setiap halaman. Cara visualisasi ini merupakan cara agar kesan nyata yang ingin ditampilkan dapat lebih tersampaikan.

Pramesti (2015) mengembangkan media PopUp Book tema Peristiwa Untuk SD Negeri Pakem 1. Hasil penelitian menunjukkan media Pop Up Book mendapat respon dan antusiasme yang sangat baik pada saat pembelajaran di kelas. Menurut Dzuanda dalam Pramesti (2015), Pop-Up Book merupakan buku yang memiliki bagian yang dapat bergerak atau memilik unsur 3 dimensi serta memberikan visualisasi cerita yang menarik, mulai dari tampilan gambar yang dapat bergerak ketika halamannya dibuka.

Pop Up Card yang digunakan sebagai media pembelajaran dalam penelitian ini dapat membantu siswa dalam menguasai materi. Siswa tampak bersemangat ketika membaca materi dalam media tersebut. Hasil wawancara kepada siswa juga mengungkapkan siswa senang melihat dan membaca materi dari media karena tidak membosankan pada saat dibaca serta meningkat daya imajinasi dan kreatifitasnya. Kelebihan Pop-Up Card dapat memberikan viasualisasi cerita yang lebih menarik yang dimulai dari tampilan ilustrasi yang memiliki dimensi, gambar yang dapat bergerak, dan mampu berubah bentuk.

\section{PENUTUP \\ A. Simpulan}

Berdasarkan hasil penelitian yang telah dilakukan maka dapat disimpulkan bahwa penggunaan model pembelajaran Student Teams Achievement Divisions (STAD) dengan media Pop Up Card dapat meningkatkan aktivitas dan hasil belajar biologi siswa kelas XI SMA Siliwangi Bogor. Kemampuan guru dalam melaksanakan perencanaan pembelajaran mengalami perubahan yang baik, sehingga proses pembelajaran dapat berjalan sesuai dengan harapan.

\section{B. Saran}

Penelitian ini diterapkan pada sekolah SMA Siliwangi Bogor, untuk mengetahui bahwa hasil dari penelitian ini dapat diterapkan pada skala yang lebih luas, maka peneliti menyarankan bahwa dilakukan uji coba yang lebih luas. 


\section{DAFTAR PUSTAKA}

Fraenkel, J. R., dan Wallen, N. E., 2006. How to Design and Evaluate Research in Education. $6^{\text {th. }}$ ed. New York: McGraw-Hill

Haerullah, A. 2013. Penerapan Model Pembelajaran Kooperatif STAD untuk Meningkatkan Aktivitas dan Hasil Belajar Biologi Siswa Kelas VII MTs Negeri Kota Ternate. Jurnal Bionatur. 14.(2): 105-111

Huda, M. 2014. Model-model Pengajaran dan Pembelajaran: Isu-isu Metodis dan Paradigmatis. Yogyakarta: Pustaka Pelajar

Kesuma, M. D. H. 2013. Peningkatan Aktivitas dan Hasil Belajar Siswa SMP melalui Model Pembelajaran Kooperatif Tipe Student Teams Achievement Division dengan Metode Eksperimen. 2. (2): 1-8

Kusuma, A. D. 2013. Perancangan Buku Pop-Up Cerita Rakyat Bledhug Kuwu. Skripsi. Semarang: Fakultas Bahasa dan Seni Universitas Negeri Semarang.

Pramesti, J. 2015. Pengembangan media Pop Up Book Tema Peristiwa untuk Kelas III SD Negeri Pakem 1. Skripsi. Yogyakarta: Universitas Negeri Yogyakarta.

Rusman. 2012. Model-Model Pembelajaran. Jakarta: PT Raja Grafindo Persada

Suprijono, Agus. 2009. Cooperative Learning Teori dan Aplikasi PAIKEM. Yogyakarta: Pustaka Pelajar.

Syah, M. 2006. Psikologi Belajar. Jakarta: PT. Raja Grafindo Persada 